Original Research

\title{
Mineral Status and Interrelationship in Soil, Forage, and Blood Serum of Horses in the Rainy and Dry Seasons
}

\author{
Ignacio A. Domínguez-Vara a , Edith Sánchez-Malváez a , Pablo Medina-Navarro a , \\ Roberto Montes de Oca-Jiménez ${ }^{a}$, Rodolfo Vieyra Alberto ${ }^{a}$, Ernesto Morales-Almaraz ${ }^{a}$, \\ Jorge Lugo de la Fuente ${ }^{\mathrm{b}}$, Juan E. Sánchez-Torres ${ }^{a}$, José Luis Bórquez-Gastelum ${ }^{\mathrm{a}}$, \\ Jorge Acosta-Dibarrat ${ }^{\mathrm{a}}$, Abdelfattah Z.M. Salem ${ }^{\mathrm{a}, *}$ \\ a Departamento de Nutrición Animal, Facultad de Medicina Veterinaria y Zootecnia, Universidad Autónoma del Estado de México, México \\ ${ }^{\mathrm{b}}$ Departamento de Edafología y Ambiente, Facultad de Ciencias, Universidad Autónoma del Estado de México, México
}

\section{A R T I C L E I N F O}

\section{Article history:}

Received 27 August 2016

Received in revised form 19 September 2016

Accepted 21 September 2016

Available online 4 October 2016

\section{Keywords:}

Horses

Mineral

Soil

Forage

Serum

Season

\begin{abstract}
A B S T R A C T
The objective was to evaluate the content of $\mathrm{P}, \mathrm{Ca}, \mathrm{Mg}, \mathrm{K}, \mathrm{Na}, \mathrm{Cu}, \mathrm{Fe}, \mathrm{Zn}, \mathrm{Se}$, and $\mathrm{Mn}$ in soil, forage, and serum of horses in several production units (PU) during rainy and dry seasons and predict their concentration in serum from their content in soil and forage. Soil and pastures were sampled in the dry (November-December) and in rainy seasons (June-July), and blood samples were collected from the jugular vein of 76 horses in both seasons at four PU. The experimental design was a completely random design within a $4 \times 2$ (PU $\times$ season) factorial arrangement of treatments. Concentration of minerals in soil differed $(P<$ .05 ) among PU, and contents of $\mathrm{P}, \mathrm{Ca}, \mathrm{Mg}$, and $\mathrm{K}$ were low; $\mathrm{Zn}$ and Fe were high; and $\mathrm{Cu}$ and Mn were adequate. Mineral concentrations in forage differed among PU and season, and among PU within season (interaction $P<.05$ ). Contents of $\mathrm{Ca}, \mathrm{Mg}, \mathrm{Na}, \mathrm{Zn}$, and Cu were low; Fe was high; and $\mathrm{P}, \mathrm{K}, \mathrm{Se}$, and $\mathrm{Mn}$ adequate. The mineral concentration in equine blood serum differed $(P<.05)$ among $\mathrm{PU}$ and season. Overall, there were deficiencies of $\mathrm{P}, \mathrm{Ca}, \mathrm{Mg}$, $\mathrm{Na}, \mathrm{Cu}$, and $\mathrm{Se}$, but adequate amounts of $\mathrm{K}, \mathrm{Zn}$, and $\mathrm{Fe}$. There are imbalances of minerals in soil and forages which effected their concentration inequine blood.
\end{abstract}

(c) 2016 Elsevier Inc. All rights reserved.

\section{Introduction}

The feeding and nutrition of livestock becomes less of an empirical endeavor when the information necessary to scientifically balance diets is available [1]. Equine performance is influenced by genetic, nutritional, health, and management factors. Thus, optimal nutrition is essential for a foal to achieve maximal performance. Likewise, nutrition is fundamental for husbandry purposes as several reproductive problems due to nutritional deficiencies have been identified [2].

\footnotetext{
* Corresponding author at: Abdelfattah Z.M. Salem, Departamento de Nutrición Animal, Facultad de Medicina Veterinaria y Zootecnia, Universidad Autónoma del Estado de México, C.P. 50000 Toluca, México.

E-mail address: asalem70@yahoo.com (A.Z.M. Salem).
}

Mineral sources for horses are typically forages and grain cereals. As mineral availability depends on soil concentration, forage maturity, plant species, harvest conditions, and method of conservation. Mineral contents of feeds can cause mineral variation in blood serum [3]. According to the NRC [4], there are 14 essential minerals for equines, 7 macrominerals (i.e., $\mathrm{Ca}, \mathrm{P}, \mathrm{Mg}, \mathrm{K}, \mathrm{Na}, \mathrm{Cl}, \mathrm{S}$ ), and 7 microminerals (i.e., $\mathrm{Cu}, \mathrm{Zn}, \mathrm{Fe}, \mathrm{Se}, \mathrm{Co}, \mathrm{I}, \mathrm{Mn}$ ).

In Mexico, there are $\sim 1.33$ million horses, of which $\sim 74,000$ are in the State of Mexico [5]. In many regions in the country, horses are important for agricultural activities, but nutritional problems are often not addressed. For this reason, research in equine mineral nutrition is scarce and frequently minerals are not taken into account when balancing rations. Signs and symptoms associated with mineral deficiencies have been identified in grazing horses, 
yet few are diagnosed as a result of laboratory assays. Research conducted in the central region of Mexico suggests mineral deficiencies in soils, forages, as well as bovine and ovine blood serum [6-8].

The purpose of the present study was to obtain information on the mineral nutrition of grazing horses fed feed supplements in the rainy and dry seasons. In addition, identification of mineral imbalances as well as the relationships between minerals in soils, plants, and blood serum were evaluated.

\section{Materials and Methods}

\subsection{Location and Agroecological Characterization}

The study took place in four different horse production units (PU) in rural and suburban areas located in the Valley of Toluca (Mexico), which is at a northern latitude between $19^{\circ} 51^{\prime}$ and $19^{\circ} 15^{\prime}$ and a longitude between $99^{\circ} 26^{\prime}$ and $99^{\circ}$ 28 '. The altitude is between 1,850 and $2,670 \mathrm{~m}$ asl, and the precipitation is 800 and $1,000 \mathrm{~mm}$ in spring and summer. The weather is temperate subhumid, temperatures ranging between $12^{\circ} \mathrm{C}$ and $18^{\circ} \mathrm{C}$, classified as $\mathrm{Cb}$ (W2) [9]. The PU had similar management systems that consisted of stall time and some grazing, but without mineral supplementation. The soil is variably classified as Gleysol, Cambisol, Andosol, and Litosol [10]. The paddocks in the PU were 1.5 to 3 hectares, and the prevalent grass species were Lupinus montanus, Lupinus exaltatus, the native grass Muhlenbergia mabroura, Stipa ichum, Tagetes coronopifolia, and the exotic grass Pennisetum clandestinum.

\subsection{Animals and Management}

In the PU used, there were adult horses that grazed and were fed a concentrate without mineral supplementation. The PU with the number of horses and paddocks were:

- Hurtado with 10 Quarter horses and 3 ha,

- La Joya with 23 Spanish horses and 1.5 ha,

- Zinacantepec with 37 Warmblood horses and 1.5 ha, and

- Jilotepec with 75 Warmblood horses and 2.5 ha.

Prior to initiation of the study, we identified signs of malnutrition, stunted growth, emaciation, weight loss, alopecia, leukoderma, fatigue, and lameness, possibly due to mineral unbalances in all PU. The horses in both La Joya and Hurtado had an adequate body score, those in Zinacantepec and Jilotepec had some angular deviations, and in Zinacantepec, there were some issues of articular and tendon sheath effusion, which were clinically attributable to the intense activity of these horses.

\subsection{Sampling Procedures and Chemical Analyses}

From every PU, samples were obtained from soil (rainy season), as well as forage and equine blood during the rainy (July) and dry (November) seasons of 2005. Soil and forage sampling techniques were stratified by dividing the grazing area of all PU into 2,500 to $3,000 \mathrm{~m}^{2}$ parcels. In each parcel, from 8 to 20 primary samples of 0.5 to $1 \mathrm{~kg}$ of soil were obtained, and 5 combined samples ( $1 \mathrm{~kg}$ ) were created for each PU. Forage was collected in the same area as the soil samples, and five combined samples per PU were obtained by hand plucking [11]. Table 1 shows the soil, forage, and serum samples obtained. Blood was obtained from the jugular vein of 20 adult horses. Serum was then isolated from blood, labeled and preserved at $-20^{\circ} \mathrm{C}$ for later analysis. Soil P was measured by means of the Bray-P1 method with samples for $\mathrm{Ca}, \mathrm{Mg}$, and $\mathrm{K}$ analysis extracted with 1 molar ammonium acetate prior to $\mathrm{Ca}$ and $\mathrm{Mg}$ assays determined by the volumetric ethylenediaminetetraacetic acid method and $\mathrm{K}$ by flame emission spectrophotometry. Samples for $\mathrm{Zn}$, $\mathrm{Cu}$, and $\mathrm{Fe}$ were extracted in diethhylenetriaminepentaacetic acid and assayed by atomic absorption spectrophotometry [12]. Soil pH was measured in a 1:2 water dilution, and electric conductivity in a saturation extract by means of a conductimeter, and organic matter (OM) by Walkley and Black's method [13]. In forages and serum samples, P was measured by colorimetry [14]; Ca, $\mathrm{Mg}, \mathrm{K}, \mathrm{Na}, \mathrm{Cu}, \mathrm{Zn}$, and Fe by atomic absorption spectrophotometry [12]; and Se by spectrofluorometry [15].

\subsection{Statistical Analysis}

A completely randomized design was used. In a linear model, soil mineral analysis considered PU effect as a fixed effect. For analysis of mineral concentrations in forage and serum, the effects considered were: PU, season, and its interaction. For the minerals in equine serum, a regression analysis was performed by means of the stepwise procedure [16]. Variance analysis was completed and means compared by means of Tukey's test [17].

\section{Results}

Differences $(P<.05)$ occurred due to PU in $\mathrm{P}, \mathrm{Ca}, \mathrm{Mg}, \mathrm{Zn}$, $\mathrm{Fe}$, and $\mathrm{Mg}$ content as well as in $\mathrm{pH}, \mathrm{OM}$, and conductivity (Table 2). The PU effect also occurred $(P<.05)$ in $\mathrm{Cu}$ and $\mathrm{Fe}$ content, whereas there was a season effect $(P<.05)$ in forage $\mathrm{Na}, \mathrm{Cu}$, and $\mathrm{Fe}$ (Table 3 ). Table 4 shows forage content of $\mathrm{P}, \mathrm{Ca}, \mathrm{Mg}, \mathrm{K}, \mathrm{Zn}, \mathrm{Se}$, and $\mathrm{Mn}$. Production unit and season effects occurred in the mineral content of the serum (Table 5). The regression equations predicted $(P<.05) \mathrm{P}, \mathrm{Ca}$, $\mathrm{Na}, \mathrm{Cu}, \mathrm{Zn}, \mathrm{Fe}$, and Se contents in equine serum from forage mineral content (Table 6).

Table 1

Soil, forage, and equine serum samples, as analyzed by production unit and season.

\begin{tabular}{|c|c|c|c|c|c|}
\hline \multirow[t]{2}{*}{ Production unit (PU) } & \multirow[t]{2}{*}{ Soil (Dry) } & \multicolumn{2}{|c|}{ Forage } & \multicolumn{2}{|c|}{ Serum $^{\mathrm{a}}$} \\
\hline & & Dry & Wet & Dry & Wet \\
\hline Hurtado & 10 & 8 & 4 & 11 & 10 \\
\hline Zinacantepec & 6 & 6 & 6 & 21 & 20 \\
\hline La Joya & 6 & 16 & 10 & 25 & 17 \\
\hline Jilotepec & 8 & 8 & 10 & 26 & 22 \\
\hline Total $^{\mathrm{b}}$ & 30 & 38 & 30 & 83 & 69 \\
\hline
\end{tabular}

a Total horses sampled per season.

b Total samples analyzed: soil 30, forage 68, and serum 152 (mean per season $=76$ ). 
Table 2

Mineral concentration, $\mathrm{pH}, \mathrm{OM}$, and electric conductivity $(\mathrm{dSm} / 1$, desisiemmens/m) in soils from four stables of horses.

\begin{tabular}{|c|c|c|c|c|c|c|c|c|c|c|c|}
\hline Production unit (PU) & $\mathrm{P}(\mathrm{ppm})$ & $\mathrm{Ca}(\mathrm{ppm})$ & $\operatorname{Mg}(\mathrm{ppm})$ & $\mathrm{K}(\mathrm{ppm})$ & $\mathrm{Zn}(\%)$ & $\mathrm{Cu}(\%)$ & $\mathrm{Fe}(\%)$ & Mn (\%) & $\mathrm{pH}(\%)$ & MO (\%) & $\mathrm{dS} / \mathrm{m}(\%)$ \\
\hline Hurtado & $8.4^{\mathrm{b}}$ & $600^{b}$ & $20.0^{\mathrm{d}}$ & $20.4^{\mathrm{a}}$ & $1.5^{\mathrm{c}}$ & $0.8^{\mathrm{a}}$ & $44.0^{\mathrm{b}}$ & $27.0^{\mathrm{b}}$ & $7.5^{\mathrm{a}}$ & $1.7^{\mathrm{b}}$ & $0.14^{\mathrm{ab}}$ \\
\hline Zinacantepec & $16.2^{\mathrm{a}}$ & $1900^{a}$ & $50.3^{\mathrm{b}}$ & $30.0^{\mathrm{a}}$ & $15.5^{\mathrm{a}}$ & $1.3^{\mathrm{a}}$ & $16.7^{\mathrm{c}}$ & $65.2^{\mathrm{a}}$ & $6.3^{\mathrm{b}}$ & $8.4^{\mathrm{b}}$ & $0.17^{\mathrm{a}}$ \\
\hline La Joya & $9.5^{\mathrm{ab}}$ & $7.0^{\mathrm{b}}$ & $3.7^{c}$ & $2.5^{\mathrm{a}}$ & $8.9^{\mathrm{ab}}$ & $1.0^{\mathrm{a}}$ & $95.7^{\mathrm{a}}$ & $82.5^{\mathrm{a}}$ & $5.5^{\mathrm{c}}$ & $3.7^{\mathrm{b}}$ & $0.07^{\mathrm{c}}$ \\
\hline Jilotepec & $16.7^{\mathrm{a}}$ & $17.2^{\mathrm{b}}$ & $6.7^{\mathrm{a}}$ & $2.3^{\mathrm{a}}$ & $6.9^{\mathrm{bc}}$ & $4.5^{\mathrm{a}}$ & $63.5^{\mathrm{b}}$ & $22.5^{b}$ & $6.2^{\mathrm{b}}$ & $4.9^{\mathrm{b}}$ & $0.12^{\mathrm{b}}$ \\
\hline SEM & 1.4 & 0.9 & 0.3 & 0.2 & 1.4 & 0.8 & 4.8 & 5.3 & 0.15 & 1.6 & 0.03 \\
\hline PU effect & $*$ & * & * & ns & * & ns & * & $*$ & $*$ & $*$ & $*$ \\
\hline Critical level $^{\mathrm{e}}$ & 25 & 900 & 30 & 60 & 2.0 & 0.60 & 4.5 & - & & & \\
\hline Deficiency $^{\mathrm{f}}$ & $32 / 94$ & $34 / 100$ & $34 / 100$ & $34 / 100$ & $18 / 53$ & $4 / 12$ & $0 / 0$ & - & & & \\
\hline
\end{tabular}

Abbreviations: ns, no significant; SEM, standard error of mean.

a,b,c,d Means in the same column with distinct letter differ $\left({ }^{*} P<.01\right)$.

e Tavera [18]; Terrón and Rojo [19]; Tisdale and Nelson [20]; and De Sousa [21].

${ }^{f}$ Number and percentage of analyzed samples with deficient concentrations.

\subsection{Solis Mineral Concentration}

There was a difference $(P<.05)$ in the $P$ concentration between Hurtado and La Joya, and between Zinacantepec and Jilotepec where soil P was higher in the latter. Soil P in all PU was below the critical value of $25 \mathrm{ppm}$, meaning that all samples were $P$ deficient relative to plant growth. There was a difference $(P<.05)$ in the Ca concentration between $\mathrm{PU}$, with the highest content at Zinacantepec, and with Hurtando and La Joya below the critical value of $900 \mathrm{ppm}$. Differences $(P<.05)$ occurred for $\mathrm{Mg}$ concentration with Hurtado and La Joya having a low content, whereas Zinacantepec and Jilotepec were high.

There were no differences for $\mathrm{K}$ concentration between $\mathrm{PU}$, and all PU were below the critical value of $60 \mathrm{ppm}$, meaning that $92 \%$ of samples were $\mathrm{K}$ deficient. The concentration of $\mathrm{Zn}$ in the PU differed $(P<.05)$, although only in Hurtado was the $\mathrm{Zn}$ concentration below $2 \mathrm{ppm}$, meaning that $60 \%$ of samples were $\mathrm{Zn}$ deficient.

There were no differences between soils for $\mathrm{Cu}$, but Hurtado and La Joya had values slightly above $0.6 \mathrm{ppm}$. The presence of absorption limiting factors such as excess Fe is likely to cause a $\mathrm{Cu}$ deficiency in forages. All soils had an excess of Fe, with values well above $4.5 \mathrm{ppm}$. No differences occurred for Mn among PU, and Mn in these soils was normal.

Table 3

Concentration of $\mathrm{Na}, \mathrm{Cu}$, and $\mathrm{Fe}$ (ppm) in native forages from four stables of horses.

\begin{tabular}{llcc}
\hline Production unit (PU)/Season & $\mathrm{Na}(\% \mathrm{DM})$ & $\mathrm{Cu}(\mathrm{ppm})$ & $\mathrm{Fe}(\mathrm{ppm})$ \\
\hline Hurtado & $0.10^{\mathrm{a}}$ & $4.3^{\mathrm{b}}$ & $369.0^{\mathrm{b}}$ \\
Zinacantepec & $0.08^{\mathrm{a}}$ & $6.7^{\mathrm{a}}$ & $231.8^{\mathrm{b}}$ \\
La joya & $0.06^{\mathrm{a}}$ & $5.5^{\mathrm{ab}}$ & $261.4^{\mathrm{b}}$ \\
Jilotepec & $0.07^{\mathrm{a}}$ & $6.7^{\mathrm{a}}$ & $1,149.3^{\mathrm{a}}$ \\
SEM & 0.03 & 0.60 & 115.7 \\
Dry season & $0.03^{\mathrm{y}}$ & $4.8^{\mathrm{y}}$ & $553.2^{\mathrm{x}}$ \\
Wet season & $0.13^{\mathrm{x}}$ & $7.0^{\mathrm{x}}$ & $499.2^{\mathrm{y}}$ \\
SEM & 0.06 & 1.2 & 231.4 \\
Requirement & 0.18 & 10.00 & 50.0 \\
Critical level $^{\mathrm{e}}$ & 0.06 & 5.00 & 30.0 \\
Deficiency $^{\mathrm{f}}$ & $62 / 88$ & $68 / 97$ & $8 / 11$ \\
\hline
\end{tabular}

Abbreviation: SEM, standard error of mean.

$\mathrm{a}, \mathrm{b}, \mathrm{c} ; \mathrm{x}, \mathrm{y}$ Means with distinct letter in the same column differ $(P<.05)$.

d Requirements of adult horses $450-500 \mathrm{~kg}$ BW, moderate physical work [22].

e NRC [22]; Shotola et al [23]; Harper and Gill [24]; and ARC [25].

${ }^{f}$ Number and percentage of deficient analyzed samples.
There were differences $(P<.05)$ in soil pH among PU and for OM content which averaged $4.67 \%$. For soil electric conductivity, differences $(P<.05)$ occurred between PU, with La Joya having the lowest value $(0.07 \mathrm{dS} / \mathrm{m})$.

\subsection{Forages Mineral Concentration}

For P, except for Zinacantepec during the dry season and Hurtado during the rainy season, the other PU, and between seasons, had forages which did not meet the nutrient requirement of horses. Furthermore, 98\% of samples were $\mathrm{P}$ deficient and coincident with the previously noted soil P deficiency. The Ca content in both seasons at Hurtado, during the rainy season in La Joya, and during the dry season in Jilotepec was all below the critical value. Although $85 \%$ of samples were deficient for $\mathrm{P}$, this was only true for only $30 \%$ of soil samples. The effect $(P<.05)$ of the interaction of PU and season for forage Ca may be because in La Joya, during the rainy season, Ca was lower than during the dry season.

Except for Jilotepec during the dry season, $\mathrm{Mg}$ content was adequate at all other PU and seasons and met equine requirements. For $\mathrm{K}$, an interaction occurred $(P<.05)$ for $\mathrm{PU}$ by season. There were no differences in Na concentrations among PU, and in each, the mean was above the critical value. However, only in Hurtado during the rainy season was the requirement for equines met as $91 \%$ of samples were Na deficient. For Fe, differences $(P<.05)$ occurred among PU. Except for Zinacantepec during the dry season, forage $\mathrm{Zn}$ was deficient and did not satisfy the requirement of horses. The interaction $(P<.05)$ of PU by season effected forage Se, but it was not deficient. In Hurtado and La Joya during the rainy season, forage Mn did not meet equine requirements.

\subsection{Equine Blood Serum Mineral Concentration}

Mean serum P was below the critical value for horses in Zinacantepec and La Joya during the dry season, and serum Ca was above the critical value for horses. The interaction $(P$ $<.05$ ) of PU by season may be because in Hurtado and Jilotepec during the dry season the Ca content was higher than during the rainy season. The $\mathrm{Mg}$ content in horses in Zinacantepec during both seasons, in La Joya during the dry 
Table 4

Effect of interaction production unit by season on mineral content of native forages from four stables.

\begin{tabular}{|c|c|c|c|c|c|c|c|c|}
\hline Production unit (PU) & Season & $\mathrm{P}(\% \mathrm{DM})$ & Ca (\%DM) & $\mathrm{Mg}(\% \mathrm{DM})$ & $\mathrm{K}(\% \mathrm{DM})$ & $\mathrm{Zn}(\mathrm{ppm})$ & Se (ppm) & $\mathrm{Mn}(\mathrm{ppm})$ \\
\hline \multirow[t]{2}{*}{ Hurtado } & Dry & $0.25^{\mathrm{bc}}$ & $0.22^{\mathrm{b}}$ & $0.14^{\mathrm{a}}$ & $1.32^{\mathrm{b}}$ & $22.9^{\mathrm{b}}$ & $0.74^{\mathrm{a}}$ & $33.4^{\mathrm{bc}}$ \\
\hline & Wet & $0.30^{\mathrm{ab}}$ & $0.28^{\mathrm{b}}$ & $0.19^{a}$ & $2.18^{\mathrm{ab}}$ & $18.0^{\mathrm{b}}$ & $0.24^{\mathrm{d}}$ & $22.0^{\mathrm{c}}$ \\
\hline \multirow[t]{2}{*}{ Zinacantepec } & Dry & $0.33^{\mathrm{a}}$ & $0.37^{\mathrm{b}}$ & $0.20^{\mathrm{a}}$ & $2.56^{\mathrm{ab}}$ & $33.4^{\mathrm{a}}$ & $0.52^{\mathrm{bc}}$ & $135.8^{\mathrm{a}}$ \\
\hline & Wet & $0.22^{\mathrm{cd}}$ & $0.69^{a}$ & 0.15 & $2.22^{\mathrm{ab}}$ & $17.4^{\mathrm{b}}$ & $0.26^{\mathrm{d}}$ & $48.4^{\mathrm{bc}}$ \\
\hline \multirow[t]{2}{*}{ La Joya } & Dry & $0.22^{\mathrm{dc}}$ & $0.42^{\mathrm{b}}$ & $0.15^{\mathrm{a}}$ & $1.95^{\mathrm{ab}}$ & $15.9^{\mathrm{b}}$ & $0.53^{\mathrm{b}}$ & $35.2^{\mathrm{bc}}$ \\
\hline & Wet & $0.28^{\mathrm{abc}}$ & $0.23^{\mathrm{b}}$ & $0.17^{\mathrm{ab}}$ & $2.42^{\mathrm{ab}}$ & $17.4^{\mathrm{b}}$ & $0.20^{\mathrm{d}}$ & $27.7^{c}$ \\
\hline \multirow[t]{2}{*}{ Jilotepec } & Dry & $0.17^{\mathrm{d}}$ & $0.22^{\mathrm{b}}$ & $0.09^{c}$ & $3.00^{\mathrm{a}}$ & $16.6^{\mathrm{b}}$ & $0.30^{\mathrm{d}}$ & $76.6^{\mathrm{b}}$ \\
\hline & Wet & $0.24^{\mathrm{c}}$ & $0.41^{\mathrm{b}}$ & $0.13^{\mathrm{bc}}$ & $1.42^{\mathrm{b}}$ & $20.2^{\mathrm{b}}$ & $0.35^{\mathrm{cd}}$ & $64.3^{\mathrm{bc}}$ \\
\hline SEM & & 0.006 & 0.60 & 0.005 & 0.14 & 1.19 & 0.02 & 5.07 \\
\hline Probability $(P<)$ & & .001 & .01 & .002 & .01 & .03 & .006 & .03 \\
\hline Requirement $^{\mathrm{e}}$ & & 0.30 & 0.35 & 0.09 & 0.40 & 40.00 & 0.10 & 40.00 \\
\hline Critical level $^{\mathrm{f}}$ & & 0.15 & 0.20 & 0.05 & 0.20 & 30.0 & 0.05 & 30.00 \\
\hline Deficiency $^{\mathrm{g}}$ & & $67 / 98$ & $58 / 85$ & $67 / 98$ & $0 / 0$ & $68 / 100$ & $12 / 17$ & $43 / 63$ \\
\hline
\end{tabular}

Abbreviation: SEM, standard error of mean.

a,b,c,d Means with distinct letter in the same column differ $(P<.05)$.

e Requirements of adult horses 450-500 kg BW, moderate physical work [4,22].

f NRC [22]; Shotola et al [23]; Harper and Gill [24]; and ARC [25].

$g$ Number and percentage of deficient analyzed samples.

season, and in Jilotepec during the rainy season was below the critical value.

There were no differences in the Fe concentration; however, there was an excess of Fe in La Joya and Hurtado during the dry season and in Jilotepec during the rainy season. For Se, no PU had values below the critical level of $0.05 \mu \mathrm{g} / \mathrm{mL}$. However, 56\% of samples were Se deficient. In Hurtado during the dry season and in La Joya during the rainy season, serum Se was below $0.14 \mu \mathrm{g} / \mathrm{mL}$.

For macrominerals, serum $\mathrm{P}$ concentration $\left(R^{2}=0.89 ; P\right.$ $<.05$ ) was explained by $\mathrm{Na}, \mathrm{Ca}, \mathrm{P}, \mathrm{Cu}, \mathrm{Mn}, \mathrm{Zn}$, and Se content in forage. Likewise, serum Na concentration $\left(R^{2}=0.65\right.$; $P<.05$ ) was explained by $\mathrm{Na}, \mathrm{K}, \mathrm{Ca}, \mathrm{Cu}, \mathrm{Zn}$, and Se content in forage.

For microminerals, serum Cu content $\left(R^{2}=0.54 ; P<.05\right)$ was explained by $\mathrm{Na}, \mathrm{K}, \mathrm{Fe}, \mathrm{Mn}$, and Se content in forage; serum $\mathrm{Zn}\left(R^{2}=0.76 ; P<.05\right)$ by $\mathrm{Na}, \mathrm{Ca}, \mathrm{Mn}, \mathrm{Zn}$, and Se in forage; serum Fe $\left(R^{2}=0.97 ; P<.05\right)$ by Na, Ca, P, Cu, Mn, Zn, and $S e$ in forage and, finally, serum Se $\left(R^{2}=0.94 ; P<.05\right)$ by $\mathrm{Na}, \mathrm{K}, \mathrm{Ca}, \mathrm{P}, \mathrm{Fe}, \mathrm{Zn}$, and Se in forage.

\section{Discussion}

\subsection{Physical and Chemical Characteristics of the Soils}

Results suggest that a substantial difference between forages would have to be demonstrated in order to create an important correlation between forage mineral and serum mineral contents. Even if all physiological and hormonal effects are ignored, forages that do not show a substantive deficiency would positively correlate to all horses. Furthermore, because horses must maintain mineral homeostasis in order to live, it is paramount to account for hormonal and physiological effects. For example, blood $\mathrm{Ca}$ is regulated by hormonal balances (i.e., calcitonin and parathyroid hormone), meaning that unless a substantial excess, or lack, of Ca can be demonstrated in the forages and feeds consumed, it is likely that blood Ca for healthy horses would be expected to be within homeostatic limits. Thus because Ca content is fixed physiologically, anything that has Ca could appear to correlate with serum Ca content.

Table 5

Effect of interaction production unit by season on mineral concentration in horses serum from four stables.

\begin{tabular}{|c|c|c|c|c|c|c|c|c|c|}
\hline Production unit (PU) & Season & $\begin{array}{l}\mathrm{P}(\mathrm{mg} / \\
100 \mathrm{~mL})\end{array}$ & $\begin{array}{l}\mathrm{Ca}(\mathrm{mg} / \\
100 \mathrm{~mL})\end{array}$ & $\begin{array}{l}\mathrm{Mg}(\mathrm{mg} / \\
100 \mathrm{~mL})\end{array}$ & $\begin{array}{l}\mathrm{Na}(\mathrm{mg} / \\
100 \mathrm{~mL})\end{array}$ & $\mathrm{Zn}(\mu \mathrm{g} / \mathrm{mL})$ & $\mathrm{Cu}(\mu \mathrm{g} / \mathrm{mL})$ & $\mathrm{Fe}(\mu \mathrm{g} / \mathrm{mL})$ & Se $(\mu \mathrm{g} / \mathrm{mL})$ \\
\hline \multirow[t]{2}{*}{ Hurtado } & Dry & $3.8^{\mathrm{b}}$ & $21.9^{\mathrm{a}}$ & $2.8^{\mathrm{a}}$ & $42.2^{\mathrm{a}}$ & $3.2^{\mathrm{c}}$ & $0.9^{\mathrm{cd}}$ & $3.2^{\mathrm{b}}$ & $0.31^{\mathrm{a}}$ \\
\hline & Wet & $6.1^{\mathrm{a}}$ & $16.4^{\mathrm{bc}}$ & $2.2^{\mathrm{bc}}$ & $39.5^{\mathrm{ab}}$ & $2.6^{\mathrm{c}}$ & $1.1^{\mathrm{a}}$ & $2.6^{\mathrm{bc}}$ & $0.11^{b}$ \\
\hline \multirow[t]{2}{*}{ Zinacantepec } & Dry & $2.3^{\mathrm{c}}$ & $13.5^{c}$ & $1.7^{\mathrm{d}}$ & $32.9^{\mathrm{cd}}$ & $7.2^{\mathrm{a}}$ & $1.0^{\mathrm{abcd}}$ & $2.2^{\mathrm{c}}$ & $0.16^{\mathrm{b}}$ \\
\hline & Wet & $3.4^{\mathrm{b}}$ & $16.2^{\mathrm{bc}}$ & $1.7^{\mathrm{d}}$ & $37.4^{\mathrm{abc}}$ & $2.6^{\mathrm{c}}$ & $1.1^{\mathrm{a}}$ & $2.3^{\mathrm{bc}}$ & $0.12^{\mathrm{b}}$ \\
\hline \multirow[t]{2}{*}{ La Joya } & Dry & $2.5^{\mathrm{c}}$ & $10.8^{\mathrm{d}}$ & $1.9^{\mathrm{cd}}$ & $29.5^{\mathrm{d}}$ & $4.7^{\mathrm{b}}$ & $0.8^{\mathrm{d}}$ & $4.1^{\mathrm{a}}$ & $0.13^{b}$ \\
\hline & Wet & $3.4^{\mathrm{b}}$ & $14.3^{\mathrm{c}}$ & $2.2^{\mathrm{bc}}$ & $36.3^{\mathrm{bc}}$ & $4.0^{\mathrm{bc}}$ & $1.1^{\mathrm{ab}}$ & $2.7^{\mathrm{bc}}$ & $0.08^{\mathrm{b}}$ \\
\hline \multirow[t]{2}{*}{ Jilotepec } & Dry & $3.7^{\mathrm{b}}$ & $17.5^{\mathrm{b}}$ & $2.6^{\mathrm{ab}}$ & $40.5^{\mathrm{ab}}$ & $3.1^{\mathrm{c}}$ & $1.0^{\mathrm{abc}}$ & $2.4^{\mathrm{bc}}$ & $0.13^{\mathrm{b}}$ \\
\hline & Wet & $3.4^{\mathrm{b}}$ & $15.4^{\mathrm{bc}}$ & $1.9^{\mathrm{cd}}$ & $36.2^{\mathrm{bc}}$ & $7.2^{\mathrm{a}}$ & $0.9^{\mathrm{bcd}}$ & $3.3^{\mathrm{b}}$ & $0.16^{\mathrm{b}}$ \\
\hline SEM & & 1.14 & 0.48 & 0.07 & 0.89 & 0.26 & 0.03 & 0.15 & 0.01 \\
\hline Probability $(P<)$ & & .02 & .01 & .01 & .01 & .01 & .02 & .01 & .01 \\
\hline Normal concentration $^{\mathrm{e}}$ & & $3-5$ & $11-13$ & $2-3.5$ & 330 & $0.6-1.7$ & $0.8-2.0$ & $0.8-2.5$ & $0.15-0.25$ \\
\hline Critical level $^{\mathrm{e}}$ & & 3.0 & 9.0 & 2.0 & 300 & 0.60 & 0.65 & 1.0 & 0.05 \\
\hline Deficiency $^{\mathrm{f}}$ & & $67 / 44$ & $17 / 11$ & $74 / 48$ & $152 / 100$ & $0 / 0$ & $81 / 53$ & $0 / 0$ & $85 / 56$ \\
\hline
\end{tabular}

Abbreviations: SEM, standard error of mean.

a,b,c,d Means with distinct letter in the same column differ $(P<.05)$.

e NRC [4,22]; Puls [26]; and ARC [25].

f Number and percentage of deficient analyzed samples. 
Table 6

Regression equations to predict mineral concentration in serum of horses from four stables.

\begin{tabular}{|c|c|c|}
\hline General equation: $\mathrm{Y}=\beta_{0}+\beta_{1 \mathrm{x}}$ ó Y $=\beta_{0}+\beta_{1 \mathrm{x} 1}+\beta_{2 \times 2}$ & $R^{2}$ & $P \leq$ \\
\hline $\begin{array}{l}\mathrm{PS}^{\mathrm{a}}=4.2+107\left(\mathrm{NaF}^{\mathrm{b}}\right)-8.8(\mathrm{CaF})-25.4(\mathrm{PF})-1.4 \\
\quad(\mathrm{CuF})+0.16(\mathrm{MnF})-1(\mathrm{ZnF})+16.6(\mathrm{SeF})\end{array}$ & 0.89 & * \\
\hline $\begin{array}{l}\mathrm{CaS}=55.4-499.4\left(\mathrm{MgF}^{\mathrm{C}}\right)+104.0(\mathrm{PF})-0.0193 \\
\quad(\mathrm{FeF})+1.15(\mathrm{ZnF})-10.4(\mathrm{SeF})\end{array}$ & 0.59 & * \\
\hline $\begin{array}{l}\mathrm{NaS}=188.8-272.3(\mathrm{NaF})-29.0(\mathrm{KF})+16.6 \\
\quad(\mathrm{CaF})-10.1(\mathrm{CuF})+2.5(\mathrm{ZnF})-172.5(\mathrm{SeF})\end{array}$ & 0.65 & * \\
\hline $\begin{array}{l}\mathrm{CuS}^{\mathrm{c}}=-1.7+9.13(\mathrm{NaF})+0.56(\mathrm{KF})+0.0002 \\
\quad(\mathrm{FeF})-0.002(\mathrm{MnF})+2.06(\mathrm{SeF})\end{array}$ & 0.54 & * \\
\hline $\begin{array}{l}\mathrm{ZnS}=-8.7+120.5(\mathrm{NaF})-12.65(\mathrm{CaF})+64.8 \\
\quad(\mathrm{PF})+0.25(\mathrm{MnF})-1.7(\mathrm{ZnF})+34.1(\mathrm{SeF})\end{array}$ & 0.76 & * \\
\hline $\begin{array}{l}\mathrm{FeS}=-4.6+295(\mathrm{NaF})-21.8(\mathrm{CaF})+142(\mathrm{PF})-3.6 \\
\quad(\mathrm{CuF})+0.6(\mathrm{MnF})-3.6(\mathrm{ZnF})+61(\mathrm{SeF})\end{array}$ & 0.97 & $*$ \\
\hline $\begin{array}{l}\mathrm{SeS}=-9.3+41(\mathrm{NaF})+2.7(\mathrm{KF})+2(\mathrm{CaF})+31 \\
\quad(\mathrm{PF})+0.003(\mathrm{FeF})-0.25(\mathrm{ZnF})+14.5(\mathrm{SeF})\end{array}$ & 0.94 & * \\
\hline \multicolumn{3}{|c|}{$\begin{array}{l}{ }^{*} P<.05 . \\
\text { a } \text { Macrominerals in serum (mg/dL): CaS, MgS, KS, NaS. } \\
\text { b } \text { Minerals in forage: (\%DM) CaF, MgF, KF, NaF, PF; (ppm) CuF, ZnF, Fel }\end{array}$} \\
\hline
\end{tabular}

\subsection{Soil Mineral Concentration}

That no differences occurred for soil $\mathrm{pH}$ between PU; La Joya was moderately acidic, Zinacantepec and Jilotepec slightly acidic, and in Hurtado slightly alkaline [27]. Slightly acidic soils $(\mathrm{pH}=6.3)$ can limit plant development $[18,19,28]$.

Soils high in OM are rich in phosphates and K [20] and, during spring, $\mathrm{K}$ content increases due to OM accumulation [29]. Gastorena [30] described soils in the region as deep alluvial and of a sandy and loamy texture, with $9 \%$ to $15 \%$ $\mathrm{OM}$, and a pH of 6.0 to 6.5 , with mineral contents of: $\mathrm{P}, 8$ to 20 ppm; Ca, 800 to 2000 ppm; Mg, 200 to 400 ppm; and K, $168 \mathrm{ppm}$.

Different soil electric conductivity occurred between PU. With the lowest value for La Joya, indicating that La Joya contains saline soil, whereas the other PU have only slightly saline soils [13].

\subsection{Forage Mineral Concentration}

The interaction of PU by season in forage P may be due to Zinacantepec during the rainy season, its content was lower than in the dry season. The $P$ content $(0.25 \%$ dry matter [DB]), was lower than the $0.35 \%$ and $0.32 \%$ (DB) in ryegrass and native grasses in the same region (MoralesAlmaráz et al [6], and Domínguez-Vara and Huerta-Bravo [7]), respectively.

In La Joya, forage Ca was correlated with soil content and soil acidity ( $\mathrm{pH}=5.5)$, as occurred in our study. The forage Ca $(0.35 \%$ DB) in our study is consistent with values of Morales-Almaráz et al [6] and Domínguez-Vara and Huerta-Bravo [7]. The interaction of UP by season for forage Ca may be because of La Joya during the rainy season, it was lower than during the dry season.

Forage Mg was correlated with soil $\mathrm{Mg}$, but only in Hurtado was there a value below 20 ppm. The effect of the interaction of PU by season for forage $\mathrm{Mg}$ may be because in Zinacantepec and Jilotepec during the dry season, Mg was higher than during the rainy season. In our study, grasses were found to have $1.5 \%$ (DB) $\mathrm{Mg}$, which in enough for horses. Morales-Almaráz et al [6] and Domínguez-Vara and Huerta-Bravo [7] reported a $\mathrm{Mg}$ content of $0.25 \%$ in ryegrass and $0.26 \%$ (DB) in native grasses in the same region.

No K deficiency in forage was detected, which was not consistent with the soil $\mathrm{K}$ values, but forages had $2.13 \% \mathrm{~K}$, enough to satisfy equine requirements [22]. MoralesAlmaráz et al [6] found K content was $1.39 \%$ in ryegrass and Domínguez-Vara and Huerta-Bravo [7] 1.31\% in native grasses.

The mean Na concentration was above the critical value with $91 \%$ of samples Na deficient. Sodium deficits can affect feed and water intake leading to dehydration [22]. MoralesAlmaráz et al [6] reported a $\mathrm{Na}$ content of $0.35 \%$ (DM) for ryegrass in the same region. For $\mathrm{Cu}$, differences occurred between PU, and in all during both seasons, the forages did not supply equine requirements and $100 \%$ of samples were $\mathrm{Cu}$ deficient. Research in the region confirms an endemic $\mathrm{Cu}$ deficiency in soil, forage, and grazing sheep [7], which could be associated with high Fe contents in soil and forage, and soil acidity.

Every PU had signs of Fe excess, which was well above equine requirements during both seasons. Iron interferes with $\mathrm{Cu}$ absorption, which could affect horses [31]. In nonruminant adults, Fe absorption is $15 \%$ or less, but higher in neonates [4]. Forages and cereals contribute Fe to equine rations (150-400 and 30-90 ppm, respectively) [23].

Forages were $\mathrm{Zn}$ deficient $(20.2 \mathrm{ppm})$ in all samples which does not correspond with soil levels. MoralesAlmaráz et al [6] found a Zn content of $22.5 \mathrm{ppm}$ in ryegrass and Domínguez-Vara and Huerta-Bravo [7] reported 26 ppm for native grasses. Plants absorb less $\mathrm{Zn}$ in alkaline soils with high Ca [32]. According to Huerta [33], forages in Central Mexico are $\mathrm{Zn}$ deficient. The effect of the interaction of PU by season for $\mathrm{Zn}$ in Zinacantepec during the dry season, the $\mathrm{Zn}$ content was higher.

Forages had $0.39 \mathrm{ppm}$ Se, a higher value than found by Morales-Almaráz et al [6] in ryegrass. Díaz [34] found soil, forage, and grazing sheep to be Se deficient in the same region. The interaction of PU by season for forage Se may be Jilotepec forage Se was higher during the rainy season. In the other PU, forage Se was lower during the rainy season.

About $63 \%$ of samples were Mn deficient, which can lead to bone and cartilage problems in developing foals [22]. Forage has 25 to 190 ppm Mn and cereals 6 to 45 ppm Mn, as reported for common horse feeds [23].

\subsection{Equine Blood Serum Mineral Concentration}

About $44 \%$ of samples were P deficient. The effect of the interaction of PU by season may be because in Jilotepec during the rainy season, $\mathrm{P}$ was lower than during the dry season. According to the NRC [35], $P$ values ranging from 1.5 to $3 \mathrm{mg} / 100 \mathrm{~mL}$ are deficient and from 3.5 to $5.0 \mathrm{mg} / 100 \mathrm{~mL}$ are adequate. Horses in our study had values as low as $2.8 \mathrm{mg} / 100 \mathrm{~mL}$. Rickets is a sign of $\mathrm{P}$ deficiency in young animals [36] and P excretion increases when Ca intake is high leading to a reduced calcification which, if uncorrected, leads to poor appetite and stunted growth [4]. In contrast, excess P leads to fibrous osteodystrophy, which 
clinical signs being lameness and long bone fragility as excess $\mathrm{P}$ hinder Ca absorption and Ca concentration in soft tissues and bone [4].

According to the NRC [22], serum Ca for horses should be between 11 and $13 \mathrm{mg} / \mathrm{dL}$. In La Joya, adequate levels occurred (12.2 mg/dL), yet in the other three PUs, the serum Ca was excessive. According to Lewis [37], horses suffer from Ca and P imbalances more than any other mineral, and a Ca deficiency leads to bone resorption with fibrous tissue proliferation. In adult horses, facial and cranial bone size is augmented. Calcium deficiency can be associated with excessive $P$ intake and, during growth, bone abnormalities and deformations such as femoral head hypertrophy can be found [38].

About $48 \%$ of samples were Mg deficient. The interaction of PU by season may be because in Hurtado and Jilotepec during the dry season, the serum Mg was higher than during the rainy season. Because according to the NRC [4] and Puls [26], serum $\mathrm{Mg}$ ranges between 2 to $5 \mathrm{mg} / \mathrm{dL}$, in Zinacantepec horses were deficient, whereas the rest were normal.

According to the NRC [4] and Puls [26], normal serum K ranges between 5 and $22 \mathrm{mg} / \mathrm{dL}$. All horses had normal levels. In all PU, serum Na was below the critical value, and $100 \%$ of samples were deficient. The effect of the interaction of PU by season may be because in Hurtado and Jilotepec during the dry season serum, the Na content was higher than in the rainy season.

No $\mathrm{Zn}$ deficiencies were observed and the interaction of PU by season may be because in Hurtado, Zinacantepec, and La Joya during the dry season serum, the $\mathrm{Zn}$ content was higher. Normal serum $\mathrm{Zn}$ is 0.6 and $1.7 \mu \mathrm{g} / \mathrm{mL}[4,22,26]$. On average, serum $\mathrm{Zn}$ was above the normal value for horses in our study. According to Underwood and Suttle [39], livestock are tolerant to high dietary $\mathrm{Zn}$, but it also depends on species and $\mathrm{Ca}, \mathrm{Cu}, \mathrm{Fe}$, and $\mathrm{Cd}$ intake. Wichert et al [40] found $\mathrm{Zn}$ values in equine serum between 0.6 and $1.0 \mu \mathrm{g} / \mathrm{mL}$.

About 53\% of samples were Cu deficient. The interaction of PU by season may be because in Jilotepec, the $\mathrm{Cu}$ was higher during the dry season. According to NRC [4,22], normal serum $\mathrm{Cu}$ values are 1 to $1.9 \mu \mathrm{g} / \mathrm{mL}$; Wichert et al [40] found serum Cu values of 0.5 to $1.5 \mu \mathrm{g} / \mathrm{mL}$.

No differences occurred for Fe. The interaction of PU by season may be because in Hurtado and La Joya, serum Fe was higher during the dry seasons. Normal serum Fe ranges between 1 to $1.5 \mu \mathrm{g} / \mathrm{mL}[4,22]$ but in this study, concentrations up to $2 \mu \mathrm{g} / \mathrm{mL}$ occurred. Iron absorption depends on source, health status, age, and mineral balance [41].

The interaction of PU by season for Se may be because in Hurtado, Zinacantepec, and La Joya, Se concentration was higher during the dry season. Because, in horses, $0.14 \mu \mathrm{g} /$ $\mathrm{mL}$ Se is considered normal [4,22], La Joya had deficiencies (0.11 $\mu \mathrm{g} / \mathrm{mL})$, but Zinacantepec $(0.14 \mu \mathrm{g} / \mathrm{mL})$, Jilotepec (0.15 $\mu \mathrm{g} / \mathrm{mL})$, and Hurtado $(0.22 \mu \mathrm{g} / \mathrm{mL})$ values were normal. Harper and Gill [24] reported muscular dystrophy in Se-deficient mares and ataxia in foals, presumably due to low Se intake during gestation and lactation. Wichert et al [40] reported serum Se between 0.05 and $0.2 \mu \mathrm{g} / \mathrm{mL}$, in both summer and winter, with a mean of $0.083 \mu \mathrm{g} / \mathrm{mL}$, which is below the normal value [4,22], yet without locomotor issues.

\subsection{Prediction of Serum Mineral Concentration}

Calcium and $P$ were in 5 of 7 equations, whereas $\mathrm{Zn}$ and Se occurred in 6 . This may be relevant because $\mathrm{Zn}, \mathrm{Se}$, and $\mathrm{Cu}$ deficiencies have been identified in the region in both forage and dairy cattle [6], in forage and sheep [7,34], and also $\mathrm{Ca}$ and Fe excess in soils and forage. Forage Ca excess hinders $\mathrm{Zn}$ absorption, and Fe excess hinders $\mathrm{Cu}$ absorption, which leads to low serum values [42]. Soils with a high OM content have little available $\mathrm{Cu}$ [43]; and acidic soils $(\mathrm{pH} \leq 5.5)$ hinder plant $\mathrm{Cu}$ absorption [44]. A high content of soil $\mathrm{Zn}$ will increase its content in forage and serum, but high dietary Ca will reduce $\mathrm{Zn}$ absorption and its serum concentration [45]. Previous research in the region has developed equations to predict serum $\mathrm{Ca}, \mathrm{P}, \mathrm{K}, \mathrm{Fe}$, and $\mathrm{Cu}$ from their levels in soil and forage for dairy cattle [6]. Similar equations have been developed to predict serum $P$, $\mathrm{Zn}$, and $\mathrm{Cu}$ in sheep from soil and forage [7]. Results of those efforts are consistent with our equations.

\section{Conclusions}

Imbalances occurred in soil minerals (i.e., low concentrations of $\mathrm{P}, \mathrm{Ca}, \mathrm{Mg}$, and $\mathrm{K}$ and high concentrations of $\mathrm{Fe}$ ) as well as in forage (i.e., low concentrations of $\mathrm{Ca}, \mathrm{Mg}, \mathrm{Na}, \mathrm{Zn}$, and $\mathrm{Cu}$; and high for Fe). These low values affected blood serum mineral concentrations (i.e., marginal values for $\mathrm{P}$, $\mathrm{Ca}, \mathrm{Mg}, \mathrm{Na}, \mathrm{Cu}$, and $\mathrm{Se}$ ) and so it would be expected to have an effect on the health and the performance of horses in this region.

\section{References}

[1] Church DC. Livestock feeds and feeding. 3rd ed. U.S.A: Prentice Hall; 1991. p. 546.

[2] Pérez de Ayala EP. Nutrición y Alimentación del Caballo. XI Curso de Especialización FEDNA. Barcelona, España: Trouw Iberica, S.A; 1995. p. 195.

[3] Underwood EJ, Suttle NF. Los minerales en la nutrición del Ganado. 3a ed. España: Acribia; 2002. p. 637.

[4] NRC. Nutrient requirements of horses. National research Council. 6th ed. USA: National Academy Press; 2007.

[5] INEGI. Censo Agropecuario. Censo Agrícola, Ganadero y Forestal. Méx.: Ags.; 2009. p. 150.

[6] Morales-Almaráz E, Domínguez-Vara IA, González-Ronquillo M, Jaramillo-Escutia G, Castelán Ortega O, Pescador Salas N, Huerta Bravo M. Diagnóstico mineral en forraje y suero sanguíneo de bovinos lecheros en dos épocas en el valle central de México. Tec Pecu Méx 2007;45:329-44.

[7] Domínguez-Vara IA. Huerta-Bravo M. Concentración e interrelación mineral en suelo, forraje y suero de ovinos durante dos épocas en el Valle de Toluca, México. Agrociencia 2008;42:173-83.

[8] Vieyra AR. Perfil mineral en suelo, agua, forraje y suero sanguíneo de bovinos de doble propósito de la huasteca potosina, México. Tesis de Maestría. FMVZ. Toluca, México: Universidad Autónoma del Estado de México; 2012. p. 110.

[9] García E, de M. Modificaciones al sistema de clasificación climática de Köppen. 4a ed.; 1988. p. 217. Instituto de Geografía, UNAM; México, D.F.

[10] INEGI. Territorio Nacional. [en línea]. Disponible en www.inegi.org. mx. (revisado 15 de marzo de 2011); 2010.

[11] Wayne CC. Symposium on nutrition of forages and pastures: collecting forages samples representative of ingested material of grazing animals for nutritional studies. J Anim Sci 1964;23:265-70.

[12] Fick KR, Mc Dowell LR, Wilkinson NS, Funk DJ, Conrad JH, Valdivia R. Métodos de análisis de minerales para tejidos de plantas y animales. USA: Departamento de Ciencia Animal. Universidad de Florida; 1979. p. 135. 
[13] Semarnat. Norma Oficial Mexicana 021. Especificaciones de fertilidad, salinidad y clasificación de suelos, muestreo y análisis. México: Diario Oficial de la Federación; 2000.

[14] Harris W, Popat D. Determination of the phosphorus content of lipids. J Am Oil Chem Soc 1954;31:124.

[15] AOAC. Oficial methods of analysis. 15th ed. Arlington, VA: Association of Oficial Analytical Chemist; 1990.

[16] Statistical Analysis System. Software (versión 9.0). User's Guide; 2002. N.C., USA.

[17] Steel RGD, Torrie JH, Dickey DA. Principles and procedures of statistics a biometrical approach. 3rd ed. United States of America: McGraw-Hill Series in Probability and Statistics; 1997. p. 622.

[18] Tavera G. Criterios para interpretación y aprovechamiento de los reportes de laboratorio para las áreas de asistencia técnica. Publ. No. 3. La laguna, Coahuila, México: Sociedad Mexicana de la Ciencia del Suelo; 1985. p. 75.

[19] Terrón PV, Rojo HC. Condiciones del Suelo y Desarrollo de las Plantas según Russell. Madrid, España: Mundi Prensa; 1992. p. 250.

[20] Tisdale S, Nelson W. Soil Fertility and Fertilizers. NY, USA: McMilan PubCo; 1975.

[21] De Sousa JC. Interrelationships among mineral levels in soil, forages, and animal tissues on ranches in Northern Mato Grosso Brasil. Ph.D. Dissertation. Gainesville, Florida, U.S.A: University of Florida; 1978. p. 135.

[22] NRC. Nutrient requirements of horses. USA: National Research Council. National Academy Press; 1989.

[23] Shotola K, Culver A, Wall L. Horse nutrition. Bu: Ohio State University; 2011.

[24] Harper F, Gill W. Minerals for horses, Part II. Trace minerals. Tennessee horse Express. Tennessee: Department of Animal Science. University of Tennessee Institute of Agriculture, U.S. Department of Agriculture and Country Governments Cooperating; 2006. p. 4. 25, 1.

[25] ARC. Agricultural Research Council. Nutrient requirements of ruminant livestock. Commonwealth agricultural Bureau. UK: Farm Ham Royal; 1980.

[26] Puls R. Mineral levels in animal health. 2nd ed. Canada: Diagnostic data. Sherpa International. Clearbrook B. C. Trinity Western University Press; 1988.

[27] Fitzpatrick EA. Introducción a la ciencia de los Suelos. México: Trillas; 1996. p. 250

[28] Reid RL, Horvath D. Soil chemistry and mineral problems in farm livestock. A review. Anim Feed Sci Technol 1980;5:95-112.

[29] Black CA. Soil plants relationships. 2nd ed. New York, USA: Willey; 1968.
[30] Gastorena de AG. Propiedades físicas y químicas del suelo del Valle de Toluca. México, D.F.: Congreso Nacional de la Ciencia del Suelo; 1971. p. 195.

[31] Humphries WE, Breme I, Phillippo M. The influence of dietary iron on copper metabolism in the calf. In: Mills CF, Bremner I, Chesters JK, editors. Proc. Fifth Int. Symposium on Trace Element in man and animals. Farnham Royal, U.K: Commonwealth Agricultural Bureaux; 1985. p. 371.

[32] Miller WJ. In: O’Dell B, Miller EK, Miller WJ, editors. Copper and zinc in ruminant nutrient. West Des Moines, IA: National Feeds Ingredients Association; 1979. p. 180.

[33] Huerta B. Nutrición mineral de rumiantes en pastoreo. Memorias Curso Alternativas de Manejo de Bovinos Carne en Pastoreo. México: Universidad Autónoma Chapingo; 1997. p. 142.

[34] Díaz ZS. Determinación de la actividad de Glutation Peroxidasa (GSH-Px) y niveles de selenio en sangre de ovinos y niveles de selenio en suelo y pasto de áreas ovinas de San Felipe del Progreso, México. Tesis de Maestría. Toluca, México: FMVZ-UAEM; 1993. p. 115.

[35] NRC. Mineral tolerance of animals. 2nd ed. USA: National Academy Press; 2005.

[36] Church DC, Pond WG, Pond K. Fundamentos de Nutrición y Alimentación de Animales. 2nd ed. México: Limusa; 2002. p. 636.

[37] Lewis LD. Alimentación y cuidado del caballo. Argentina: Intermedia. B.A.; 1991. p. 350.

[38] Rosset WM. Alimentación de los caballos. Barcelona, España: Aedos; 1993. p. 350.

[39] Underwood EJ, Suttle NF. The mineral nutrition of livestock. USA: Cabi Publ; 1999.

[40] Wichert B, Frank T, Kienzle E. Zinc, cooper and selenium intake and status of horses in Bavaria. Expanded Abstract. J Nutr 2002;132: 1776S-7S.

[41] Bromiley M. Métodos naturales para la salud del caballo. España: Acribia; 1994.

[42] Phillippo M. The role of dose response trials in predicting trace elements deficiency disorders. Br Soc Anim Prod 1983;7:51-9.

[43] Haynes RJ. Micronutrients status of a group of soils in Cantenbury New Zealand, as measured by extraction with EDTA, DTPA and HCL, and its relationship with plant response to applied $\mathrm{Cu}$ and $\mathrm{Zn}$. J Agric Sci 1997;129:325-33.

[44] COSAC. Trace elements deficiency in ruminants; 1982. p. 49-50. Edinburgh, Scotland: SAC.

[45] Aubert H, Pinta M. Trace elements in soil. New York, USA: Elsevier; 1977. p. 560. 